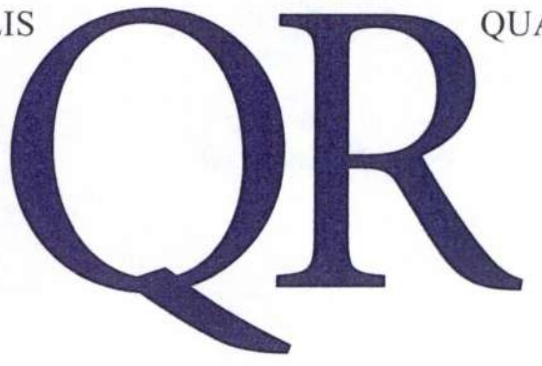

Introduction to

"Models of Monetary Economies II:

The Next Generation"

Randall Wright

Optimal Monetary Policy:

What We Know and What We Don't Know

Narayana R. Kocherlakota 
FEDERAL RESERVE BANK OF MINNEAPOLIS

\section{Quarterly Review vol. 29, No.1}

\section{ISSN 0271-5287}

This publication primarily presents economic research aimed at improving policymaking by the Federal Reserve System and other governmental authorities.

Any views expressed herein are those of the authors and not necessarily those of the Federal Reserve Bank of Minneapolis or the Federal Reserve System.

EDITOR: Arthur J. Rolnick

ASSOCIATE EDITORS: Patrick J. Kehoe, Warren E. Weber

ARTICLE EDITOR: Joan M. Gieseke

DESIGNER: Phil Swenson

TYPESETTING: Mary E. Anomalay

CIRCULATION ASSISTANT: Barbara Drucker
The Quarterly Review is published by the Research Department of the Federal Reserve Bank of Minneapolis. Subscriptions are available free of charge. This has become an occasional publication, which is published once or twice a year. The publication, however, continues to be known as the Quarterly Review for citation purposes.

Quarterly Review articles that are reprints or revisions of papers published elsewhere may not be reprinted without the written permission of the original publisher. All other Quarterly Review articles may be reprinted without charge. If you reprint an article, please fully credit the source-the Minneapolis Federal Reserve Bank as well as the Quarterly Review-and include with the reprint a version of the standard Federal Reserve disclaimer (italicized left). Also, please send one copy of any publication that includes a reprint to the Minneapolis Fed Research Department.

Electronic files of Quarterly Review articles are available through the Minneapolis Fed's home page on the World Wide Web: http://www.minneapolisfed.org.

Comments and questions about the Quarterly Review may be sent to:

Quarterly Review

Research Department

Federal Reserve Bank of Minneapolis

P. O. Box 291

Minneapolis, MN 55480-0291

(Phone 612-204-6455/Fax 612-204-5515)

Subscription requests may be sent to the circulation assistant at barbara.drucker@mpls.frb.org. 


\title{
Optimal Monetary Policy: What We Know and What We Don't Know
}

\author{
Narayana R. Kocherlakota* \\ Professor of Economics \\ University of Minnesota \\ and Consultant \\ Research Department \\ Federal Reserve Bank of Minneapolis
}

In this article, I use a subset of the conference papers as a background to discuss the state of knowledge about optimal monetary policy. Most of the papers presented at the conference are part of what one might term the basic literature of money. This literature is explicit about the frictions that make it possible for the price of money to be nonzero and (relatedly) make it possible for money to be socially beneficial. However, there is another larger body of work on monetary policy that is not explicit about monetary frictions. Instead, this applied literature adopts ad hoc constructs like transaction technologies or preferences for real balances to rationalize the positive value of fiat money and its relatively low rate of return. In this article, I argue that recent work in the applied literature has important lessons for ongoing research in the basic literature and vice versa.

I structure the article as follows: First, I review the key papers in the applied literature. The basic message of the literature is that the main existing theoretical benchmark for optimal monetary policy is the Friedman rule: The central bank should set monetary policy so that the return on money is equated to that of other assets. The government should use other instruments (like consumption taxes, wage taxes, and profit taxes) to collect its requisite tax revenues or to deal directly with inefficiencies like monopoly power or imperfect insurance.
By definition, the applied literature does not specifically describe the frictions that give rise to money demand on the part of individuals or society. In the second part of the article, I turn to the basic literature. The basic literature is all about those frictions. One would hope that it would be able to tell us whether the Friedman rule is still optimal once we consider these frictions.

Unfortunately, it does not. I argue that all of the basic literature suffers from at least one of two crucial defects. The first is that either directly or indirectly, virtually all tax instruments beyond the inflation tax are eliminated from the model environments. The second is that it generally ignores the existence of other assets beyond money. A major lesson of the applied literature is that these two omissions are likely to matter greatly when understanding the nature of optimal monetary policy.

This lesson arises naturally from the key intuition

*This article is reprinted, with permission, from the International Economic Review (May 2005, vol. 46, no. 2, pp. 715-29): "Optimal Monetary Policy: What We Know and What We Don't Know" by Narayana R. Kocherlakota. (C) 2005 by Blackwell Publishing, www.blackwell-synergy.com. The article was edited for publication in the Federal Reserve Bank of Minneapolis Quarterly Review. Note: When this article was originally published, the author was Professor of Economics at Stanford University.

The author thanks Barbara McCutcheon, Ricardo Lagos, Warren Weber, and Randall Wright for helpful comments on prior drafts, and he thanks Winnie Choi for research assistance. He also acknowledges the support of NSF SES 0350833. The views expressed herein are those of the author and not necessarily those of the Federal Reserve Bank of Minneapolis or the Federal Reserve System. . . . 
underlying the Friedman rule. In monetary exchanges, agents endure a cost today to receive a future benefit. By making sure that the price of money rises sufficiently quickly, the Friedman rule serves to eliminate the inefficiency created by this lag. Suppose though that the government has access to a tax instrument that allows it to subsidize agents' production activities directly. Then, regardless of how it sets monetary policy, the government can undo the intertemporal inefficiency associated with monetary exchange by using this subsidy. It follows that once we allow for alternative instruments of this kind, the Friedman rule is not really a necessary feature of optimal policy in purely monetary economies: It fixes inefficiencies that can potentially be addressed using alternative instruments. ${ }^{1}$

Nonetheless, the applied literature emphasizes that the Friedman rule is an essential feature of optimal monetary policy. It obtains this result by allowing for the possibility of assets other than money. Some of these assets are, by assumption, less liquid than money itself. This difference in liquidity means that in equilibrium, money may pay a lower return than the other assets; in such equilibria, agents economize inefficiently on the use of liquidity. The applied literature shows that to fix this peculiarly monetary inefficiency, the central bank must follow the Friedman rule - it must eliminate the difference in returns between money and nonmonetary assets.

Thus, we have two distinct literatures. Each has made important contributions to our understanding of money, but each has flaws. In the applied literature, there is no explicit description of the frictions that generate a demand for money, given the presence of other assets. In the basic literature, there is only a smattering of work that endogenously generates a role for multiple riskless assets and none that allows for multiple tax instruments. My belief is that one of our main goals as monetary economists should be to better unite these two literatures - in that way, I hope to cure the problems afflicting both. I conclude with some suggestions for how to proceed along these lines.

\section{Lessons of the Applied Money Literature}

In this section, I discuss the applied money literature's results about optimal monetary policy. The basic setup is that the government needs to finance a stream of purchases that may vary over dates and states. The question is how does the government optimally use the inflation tax to accomplish this task, given all of the other instru- ments at its disposal? I go through three different types of settings, and see that the Friedman rule emerges as a remarkably robust prescription across these settings.

\section{No Heterogeneity and Flexible Prices}

In a classic 1969 essay, Friedman argues that the goal of monetary policy is to equate the return of money and bonds - that is, to set the nominal interest rate to zero. As discussed in the introduction, such a policy puts current costs and future benefits on the same footing. In this way, it cures the basic intertemporal inefficiency associated with monetary exchange.

Phelps (1973) points out that the above intuition hinges on the government's having access to lump-sum taxation. Suppose a government has to raise a given amount of resources and it has access to two sources of revenue, the inflation tax and a labor income tax. Both taxes are distortionary. Phelps argued that it is socially optimal for the government to trade off the two distortions, and that a socially optimal tax system would feature a positive nominal interest rate.

Phelps's discussion is largely an intuitive one. Chari, Christiano, and Kehoe (1996) provide a complete formal analysis of the optimal taxation problem. They consider three different representative agent models of money demand: the money-in-the-utility function model of Sidrauski (1967), the cash-credit model of Lucas and Stokey (1987), and the shopping-time model of Kimbrough (1986). In all of these models, money has a lower return in equilibrium than bonds because money is assumed to be less costly to use in transactions than other assets, including other forms of government debt. However, the models do not provide an explicit microfoundation for the superior role of money in transactions.

Chari, Christiano, and Kehoe assume that the government has access to linear taxes on labor income and to the inflation tax. Both of these taxes are distortionary. Phelps's intuition would imply that the nominal interest rate should be positive. But Chari, Christiano, and Kehoe show explicitly that Phelps's intuition is incorrect. In each of these three models, individual optimality implies a "money demand function" that describes how an individual's real money balances are related to his

\footnotetext{
${ }^{1}$ This intuition is most clearly seen in a simple cash-in-advance model in which money is the only asset and agents expend labor to produce output. Suppose the government wants to raise enough revenue to fund a particular stream of government purchases. Then, there is an indeterminacy in the optimal tax policy between the labor tax and the inflation tax.
} 
consumption, labor, and to the nominal interest rate. Chari, Christiano, and Kehoe prove that if the consumption elasticity of money demand is unity and money demand does not depend on labor supply, the optimal monetary policy is to set the nominal interest rate to be zero. ${ }^{2}$ Crucially, this result is valid regardless of the specifics of the model of money demand.

As they say themselves, Chari, Christiano, and Kehoe's finding is really a direct consequence of standard results from public finance. Diamond and Mirrlees (1971) establish the following key principle of public finance: Do not tax intermediate inputs. Money, of course, does not enter utility directly. (Even in the money-in-the-utility function model, it is real balances, not money itself, that enters utility.) Instead, it is only an intermediate input into the purchase of consumption goods. Thus, we have a simple chain of logic. Money is an intermediate input. Basic public finance tells us that intermediate inputs should not be taxed. Thus, money should not be taxed. The nominal interest rate should be zero.

\section{No Heterogeneity and Sticky Prices}

In their analysis, Chari, Christiano, and Kehoe assume that prices are fully flexible and that firms take prices as given. Yet, most central banks assume that monetary policy is effective only because firms set prices and at least some of them do not adjust prices fully in response to monetary policy shocks. Does the Chari, Christiano, and Kehoe analysis apply in a world with inflexible prices and monopolistically competitive firms?

Correia, Nicolini, and Teles (2002) argue that the answer is yes, as long as the government has access to a sufficient number of tax instruments. They consider a model environment with monopolistically competitive firms that provide intermediate goods. Some of these firms are flexible: They can adjust prices at any time. Others are inflexible: They must set prices one period in advance. Money demand is motivated through the shopping-time technology of Kimbrough (1986). Correia, Nicolini, and Teles assume that the government can use consumption taxes, wage taxes, and profit taxes, as well as seigniorage. The government has the ability to commit itself to a complete date- and state-contingent tax plan (and borrow and lend using state-contingent debt).

Correia, Nicolini, and Teles prove that in this world, it is optimal for the government to set the nominal interest rate to zero at every date and state. Basically, the Chari, Christiano, and Kehoe intermediate goods intuition goes through just as before. This may seem surprising, because there are two other inefficiencies in the production of intermediate goods that need to be corrected. First, the firms are monopolistically competitive, and so they underproduce. Second, to maintain zero nominal interest rates in the face of real shocks, inflation has to respond to real shocks. These fluctuations in inflation have the potential to create real distortions as consumers substitute away or toward firms that fail to adjust their prices in response to the economywide inflation movements.

Correia, Nicolini, and Teles show how both of these distortions can be corrected by using the consumption tax and the wage tax appropriately. First, the consumption tax and the wage tax can be set jointly in such a way so as to subsidize the supply of labor. This will have the impact of correcting the underprovision of goods generated by monopolistic competition. Second, the government can adjust the consumption tax in response to real shocks so that the flexible firms find it optimal not to change prices in response to shocks. This will eliminate the inefficient price dispersion between flexible firms and inflexible firms.

Correia, Nicolini, and Teles consider a rather specific form of price rigidity. However, the intuition behind their results transcends their particular nominal rigidity. I would summarize this intuition as follows: We generally think of the price system adjusting so as to allocate resources efficiently. But if the government sets consumption taxes correctly, resources can be efficiently allocated even though prices are not changing. Thus, in the presence of sufficiently flexible consumption taxes, nominal rigidities are irrelevant.

Correia, Nicolini, and Teles assume that the government has access to a profit tax and that it can change the consumption tax in response to shocks. Schmitt-Grohé and Uribe (2004) demonstrate that Correia, Nicolini, and Teles' results are sensitive to these assumptions. In particular, they show that as long as the profit tax is bounded away from 100 percent, and consumption taxes are fixed, it is optimal for the nominal interest rate to be positive and to be variable.

There are two reasons for their finding. The first is that the government is trying to use the inflation tax to tax monopolistic profits. Intuitively, market power is like a fixed factor. Taxes on the returns to a fixed factor are

\footnotetext{
${ }^{2}$ Correia and Teles (1999) show that the Friedman rule is valid as long as these conditions are satisfied by money demand in the neighborhood of the Friedman rule (i.e., when the nominal interest rate is near zero).
} 
lump sum, and so it is always efficient to completely tax them away. In Correia, Nicolini, and Teles' framework, the government uses the profits tax to accomplish this goal. With an upper bound on the profits tax, the government is forced to use the inflation tax as an imperfect substitute.

A second key force is that in Schmitt-Grohé and Uribe's (2004) model, the government cannot adjust the consumption tax in response to shocks. Now, a fixed nominal interest rate generates inflation fluctuations that create inefficient discrepancies in prices across firms. The government is forced to trade off between these discrepancies and the inefficiencies generated by a positive nominal interest rate.

\section{Heterogeneity and Flexible Prices}

There was a lot of discussion at the conference about the role of monetary policy in providing insurance against individual-specific shocks. da Costa and Werning (2003) analyze this question. They consider a Mirrleesian economy in which agents have fixed skills. Agent skills and labor are private information, but they combine to form observable labor income. The goal of the government in this world is to provide prenatal insurance: that is, to redistribute resources from those who are born with high skills to those who are born with low skills. The government is free to use any tax system that it wishes, including lump-sum taxes. The problem in doing so is that the government cannot observe who has high skills; its tax system must respect incentive constraints. It follows that an inflation tax is helpful to the government if and only if it relaxes the incentive constraints.

da Costa and Werning consider two types of monetary models: a cash-credit model and a shopping-time technology. They prove that the Friedman rule is optimal in the first model if individual preferences are weakly separable between labor and the consumption goods. This result is an application of the uniform commodity taxation theorem of Atkinson and Stiglitz (1976). However, da Costa and Werning also prove that the Friedman rule is optimal in the shopping-time model for any specification of the transaction technology. Intuitively, making money cheaper increases the leisure available to all agents and, because of concavity of the utility function over leisure, reduces the benefits of pretending to be less skilled. ${ }^{3}$

\section{Conclusions}

The main message of the above literature is that the Friedman rule is optimal. Money is an intermediate good, and so it should not be taxed. Governments should correct inefficiencies due to imperfect insurance, market power, or nominal rigidities using other more direct instruments. This public finance intuition is a powerful one. It is likely to be at the heart of any analysis of optimal monetary policy.

However, the applied literature leaves many questions unanswered. Let me mention three.

1. What are the microfoundations for the difference in returns between money and other assets? How are these microfoundations likely to affect the nature of optimal monetary policy?

2. What is the source of the nominal rigidities? In particular, why are the government's monetary (and possibly fiscal) policy variables so much more flexible than firm prices?

3. da Costa and Werning (2003) and Golosov, Kocherlakota, and Tsyvinski (2003) discuss the response of monetary policy to skill shocks. But how should monetary policy respond to other individual-specific shocks (such as shocks to the marginal utility of consumption)?

The hope is that the basic literature can provide answers to these and other related questions. In the next section, I assess the extent to which it does.

\section{The Basic Literature: What We Need to Learn}

At the time of the original MME1 conference, what I am calling the basic literature focused primarily on the overlapping-generations model of money. Since the publication of Kiyotaki and Wright $(1989,1991)$, the situation has changed dramatically. The new paradigm in the basic money literature is the random-matching model of Kiyotaki and Wright (1991) and its intellectual descendants. The crucial economic elements of this model are trading risk (the arrival of trading opportunities to individuals is stochastic) and decentralization (monetary exchange takes place in spatially separated pairwise meetings). As many speakers emphasized during the conference, the former assumption is essentially equivalent to assuming that individuals face shocks to their marginal utilities of consumption and to their labor productivities. Not all of the conference papers follow

\footnotetext{
${ }^{3}$ da Costa and Werning only study the case of fixed skill differences across people. However, Golosov, Kocherlakota, and Tsyvinski (2003) prove that the uniform commodity taxation theorem applies when skills vary over time according to an arbitrary stochastic process. They conjecture that their result could be used to show that the Friedman rule is valid in the case in which skills vary over time in the cash-credit model.
} 
this basic paradigm. However, they typically incorporate at least one of these two elements.

This modeling approach puts the following question at center stage: In the presence of trading risk and/or pairwise trade, what is the nature of optimal monetary policy and the costs of deviating from the optimal policy? I begin by examining the answers to this question provided by models in which money is the only asset. I then turn to models in which money coexists with assets that may have a higher rate of return. Throughout my discussion, I emphasize one of the important lessons of the applied literature: Allowing the government to use other tax instruments may have important implications for optimal monetary policy.

\section{The Friedman Rule and Heterogeneity}

In their conference paper, Bhattacharya, Haslag, and Martin (2005) emphasize that the basic intertemporal inefficiency argument underlying the Friedman rule ignores distributional effects. They study a variety of monetary economies in which agents are heterogeneous at birth (because of when they are born or the nature of their preferences). In all of these economies, if lumpsum taxes and transfers between groups are available to society, then the money supply should obey the Friedman rule in any Pareto optimum. However, if lump-sum taxes and transfers are not available to society, then there may exist Pareto optima in which the Friedman rule is no longer valid.

The intuition behind their result is simple, and is akin to arguments about the distributional effects of free trade. Suppose a society is inflating faster than the Friedman rule. If it lowers the growth rate of the money supply, there are two effects. All agents are made better off because the monetary inefficiency is reduced. However, there is a second effect: There is a transfer of wealth from agents who hold little money to those who hold more. The second effect may serve to make those with little money worse off. With lump-sum transfers, the society can undo the second effect and therefore make all agents better off. Without lump-sum transfers, the society cannot undo the second effect, and the Friedman rule is not necessarily Pareto optimal. Thus, Bhattacharya, Haslag, and Martin emphasize that the validity of the Friedman rule depends crucially on the nature of other taxes and transfers available to the government.

Bhattacharya, Haslag, and Martin's article is about economies characterized by what one might call ex ante heterogeneity: Agents are different at birth. As I mentioned earlier, much of recent monetary economics has focused on economies with ex post heterogeneity created by shocks to endowments or the marginal utility of consumption. Berentsen, Camera, and Waller (2005) discuss how monetary policy should react to this kind of ex post heterogeneity. They consider a model along the lines of Lagos and Wright (2005). In Lagos and Wright (2005), each period is divided into day and night. Agents trade money for goods during the day. At this stage, they are subject to productivity and marginal utility shocks; these create heterogeneity in money holdings. At night, agents trade money for a special general good in a Walrasian market. All of them have utility functions that are linear in their consumption of the general good. This specification means that, although there is heterogeneity in money balances in the middle of the day, it disappears by the end of the day. Agents' future trading opportunities end up being unaffected by their luck within the current decentralized market.

Berentsen, Camera, and Waller extend the LagosWright model by having two rounds of trade of money and goods during the day. During each of these rounds, agents face productivity and marginal utility shocks. Hence, the agents' luck in the first round of monetary trade influences their holdings of money going into the second round of monetary trade. How should optimal monetary policy respond to this ex post heterogeneity? Berentsen, Camera, and Waller prove that in their setting, the Friedman rule is optimal: The central bank should shrink the money supply between the daily rounds at the rate of time preference (by levying lumpsum taxes). Under this formulation, the price of money in terms of goods rises during the day; money becomes an interest-bearing asset that allows for efficient intertemporal smoothing.

I suspect though that the nightly round of money/ general goods trade plays a crucial role in Berentsen, Camera, and Waller's analysis. It completely eliminates all risk for the agents - not just at the end of the day, but during the day as well. Because of the night round of trading, all agents have the same marginal utility of money in the second daily round of trading. As long as they do not run out of money in the first daily round of trading, they also share the same marginal utility of money in that round of trading. So, even though agents have different money holdings in the middle of the day, their marginal utilities of money are not different. The ex post heterogeneity does not reflect an insurance problem that the central bank has to cure. 
Matters are very different in Green and Zhou's (2005) conference paper. They study a world in which agents experience idiosyncratic shocks to their marginal utilities of consumption and endowments; the shocks are independent and identically distributed both over time and over agents. Both record keeping and enforcement are limited. Record keeping is limited because an agent's past can only be summarized by a one-dimensional summary statistic. Enforcement is limited because an agent can always choose to exit the society and simply consume his endowment.

Green and Zhou are interested in the efficiency properties of what they term monetary mechanisms. The key feature of a monetary mechanism is that the one-dimensional summary statistic of the agent's past is updated according to a linear rule. Under this kind of mechanism, the summary statistic is easily interpreted as being money holdings. Green and Zhou interpret certain linear updating rules as representing inflationary monetary mechanisms and others as representing contractionary monetary mechanisms.

Green and Zhou prove two results. First, if agents are sufficiently patient, a laissez-faire monetary mechanism (no money growth) is nearly efficient. Intuitively, once agents are sufficiently patient, they can self-insure extremely well using only the single asset of money. Second, there exist environments in which inflationary monetary mechanisms are efficient and contractionary monetary mechanisms are not.

Like that of Bhattacharya, Haslag, and Martin, Green and Zhou's work serves to undercut the basic intuition underlying the Friedman rule. As in Bhattacharya, Haslag, and Martin, though, it is not clear why various taxes and transfers are unavailable to the government. More specifically, Green and Zhou interpret their linear mechanisms as being monetary, and that interpretation is definitely a valid one. But there is another equally natural interpretation of these linear mechanisms: They are elaborate tax/transfer systems in which the government makes reallocations based on individuals' current reports and simple summary statistics. I do not believe that it is possible to use Green and Zhou's analysis to separate out what should be done with taxes and what should be done with the growth rate of the money supply.

This kind of indeterminacy does not occur in the applied literature. In that literature, there is a margin that is distinctly associated with monetary policy: the willingness to substitute between liquid money and relatively illiquid bonds. The message of the applied literature is that the goal of monetary policy was to eliminate the liquidity premium in the return to bonds. Then, as in da Costa and Werning (2003), any necessary redistributions of wealth can be done using taxes/transfers.

\section{The Friedman Rule and Bargaining}

As I mentioned earlier, most recent work in the basic literature has focused on model economies in which agents are randomly paired in each period. There is no centralized Walrasian market.

Instead, as originally modeled by Shi (1995) and Trejos and Wright (1995), prices are determined through bargaining between the two matched parties. How does this mode of price determination affect the nature of optimal monetary policy? To answer this question, it is useful to isolate the effects of trading risk (as generated through random matching) and bargaining from one another. Using two different approaches, Lagos and Wright (2005) and Shi (1997) have constructed models in which agents are essentially insured against the trading risk present in the standard random-matching model. These models can then be used to study the impact of bargaining frictions on monetary policy.

Both Shi (1997) and Lagos and Wright (2005) find that the Friedman rule is the optimal monetary policy. There are two reasons for this result. One is the usual intertemporal inefficiency intuition that I described earlier. But, there is another force that relates to bargaining. A person who decides to hold cash is making an investment; moneyholders give up current consumption for future consumption.

However, if sellers have bargaining power, they capture part of the benefits of this investment. Hence, ex post bargaining creates a hold-up problem, which leads potential buyers to economize unduly on their money holdings. It is important that although they find that the Friedman rule is optimal, Lagos and Wright (2005) show that the hold-up problem generated by bargaining greatly magnifies the welfare cost of inflation for a given elasticity of money demand.

In both Shi (1997) and Lagos and Wright (2005), buyers and sellers cannot choose how hard to search. Lagos and Rocheteau (2005) enrich the Lagos and Wright (2005) setup by allowing buyers to choose how hard they want to search for a trading opportunity. Head and Kumar (2005) enrich the Shi (1997) model by allowing buyers to choose to see multiple prices and choose the seller with the lowest price. Lagos and Rocheteau (2005) study two types of price determination: competi- 
tive search equilibrium and Nash bargaining. ${ }^{4} \mathrm{Head}$ and Kumar focus on price posting by the seller as the mode of price determination.

Despite the similarities in their setups, the results of the two papers are surprisingly different. Lagos and Rocheteau (2005) find that the Friedman rule is optimal. In contrast, Head and Kumar (2005) find that welfare is increasing in the rate of inflation when inflation is sufficiently close to the Friedman rule. ${ }^{5}$ (There is no equilibrium in their setup when the money supply follows the Friedman rule. However, there is an equilibrium for any rate of growth higher than the Friedman rule.) More specifically, they show that buyers look at more prices in inflationary environments and so inflation serves to erode seller market power.

The general lesson of all of these papers is that the nature of price determination in decentralized trade seems to have nontrivial qualitative and quantitative effects on the welfare costs of inflation. Again, though, the welfare analysis in these papers is limited by the absence of other taxes/subsidies and other assets. For example, Lagos and Wright (2005) find large welfare costs of deviating from the Friedman rule. But these large welfare costs occur because sellers have market power. If the government had a way to subsidize production, then the welfare costs of suboptimal monetary policy would be smaller-possibly considerably so. More generally, it would be interesting to know to what extent the government could use other instruments like production subsidies or consumption taxes to cure the bargaining and search inefficiencies present in these settings.

\section{The Friedman Rule}

and the Coexistence Problem

The basic literature has focused on optimal monetary policy in model economies in which money is the only asset. As I argued in the introduction, the applied literature gives us good reasons to believe that it is important to include other assets in the analysis. Of course, any multiple-asset model of money must be consistent with two key facts. First, money has a lower return than other, apparently similar, assets (like government bonds). Second, the size of the return differential depends on monetary policy (it is higher in high-inflation environments). It has proven difficult in the context of the basic literature to generate these facts as equilibrium phenomena.

It is easy to see why this problem is so challenging. Suppose a buyer enters a store with dollars and bonds. The bonds are simply claims to dollars next period.
Why should the seller regard these objects differently? After all, from his point of view, these objects are both the same: They give him a dollar's worth of purchasing power. Yet, if sellers always treat these objects the same, there is no reason for buyers to regard them differently. Thus, it is hard to generate the equilibrium phenomenon that claims to future dollars are worth less than their face value.

Recently, there have been several attempts to come to grips with this issue. Shi's (2005) conference paper presents one argument: The government is committed to accepting only money, not unredeemed bonds, for a subset of the goods that it purchases. He shows that in the context of a random-matching model, regardless of how small the subset of cash-only purchases is, people will redeem all bonds and the price of money will be higher than the price of unredeemed bonds. Shi does not explain why the government would follow this kind of rule.

Kiyotaki and Moore's (2005) conference paper provides an intriguing explanation of why money may have a lower return than some kinds of assets with similar risk characteristics. In their model economy, agents have idiosyncratic investment opportunities that they would like to exploit. However, agents find it difficult to commit to repay loans using the returns from land. Kiyotaki and Moore show that if the enforcement constraint is sufficiently tight, money is valued and has a lower return than land because the agents' borrowing constraints bind whenever they have an investment opportunity. The Friedman rule is optimal in their setting: the government should run monetary policy to eliminate the return differential between land and money.

However, as a device for understanding optimal monetary policy, Kiyotaki and Moore's framework does have a significant weakness. In their model, only assets with enforcement problems (like land) should pay a high rate of return. In the real world, there are no enforcement problems with U.S. government debt. Hence, their model has the counterfactual prediction that government bonds, regardless of maturity, and the nature of monetary policy, should have a zero nominal rate of return.

Zhu and Wallace (2004) argue that rate-of-return dominance can be understood as the result of buyers and

\footnotetext{
${ }^{4}$ Rocheteau and Wright (2005) also study optimal monetary policy in the Lagos-Wright (2005) model under alternative forms of price determination. They do not allow for endogenous search intensity, however (although they do allow for free entry on the part of sellers).

${ }^{5}$ The bulk of Head and Kumar's article is devoted to a positive analysis of the effects of inflation on price dispersion in their setting.
} 
sellers following a particular bargaining norm in pairwise meetings. They consider a world with one-period bonds and money. At the beginning of the period, the government is willing to exchange $x$ dollars of bonds (in terms of the bonds' face value) for $p x$ dollars today, where $0<p<1$. Zhu and Wallace look at allocations that lie in the pairwise core: that is, allocations from which no matched pair would deviate.

Their main finding is that there is an allocation in the pairwise core in which agents do hold cash, even though bonds are cheaper. The intuition behind their result is that buyers and sellers adhere to a practice whereby buyers' bargaining power is an increasing function of the fraction of their money-bonds portfolio held in the form of money. In the resulting equilibrium allocation, money is worth more than bonds. Zhu and Wallace conjecture that in their model economy, it would be optimal for the government to follow the Friedman rule and set $p=1$.

All of these three models capture the fact that money has a lower return in equilibrium than other assets, without simply imposing this conclusion through an ad hoc device like a transaction technology or preferences for real balances. Just like the models in the applied literature, they all imply that the Friedman rule is optimal. Of course, these models are merely first steps. It will be interesting to see whether the Friedman rule in fact generalizes to other (as yet uninvented!) basic models that feature rate-of-return dominance.

The basic literature must also confront the problem originally posed by Phelps (1973). Suppose that the government has to raise a certain amount of revenue (for expenditures or redistribution) through a variety of distortionary means. How should it allocate those distortions across its various instruments? It is not at all obvious that the Friedman rule will be the answer to this question in the context of the models set forth in the basic literature.

\section{Conclusions}

The main message of the applied literature is that if the government has sufficient instruments, the Friedman rule is optimal. The government should correct other inefficiencies using its other instruments. The absence of an explicit microfoundation for the coexistence of money and bonds in the underlying models makes this policy prescription less compelling. Although a large amount of progress has been made, there are still two crucial weaknesses in the basic literature. First, the literature has so far not included other forms of taxation besides the inflation tax. Second, the literature is just beginning to grapple with the key question of coexistence of expensive money and cheap bonds.

\section{Looking Ahead to MME3}

I have argued that to provide a credible welfare analysis of monetary policy, the basic literature needs to build models with two key elements. First, the government must be allowed to use noninflationary tax instruments. Second, in equilibrium, agents should hold both money and other assets with potentially higher returns that depend on the specification of monetary policy.

It is impossible to know what the future of monetary theory holds. But let me mention four directions that I hope future work will pursue.

\section{Decentralized Exchange}

Following Kiyotaki and Wright (1991), modern monetary theory has put a great deal of emphasis on decentralized exchange, in which trade takes place in small groups. Price determination is no longer Walrasian in such models. Many traditional macroeconomists feel that the field has made considerable progress using the competitive paradigm, and view the emphasis on decentralized exchange with a great deal of suspicion. I think that for a long time, this mistrust was somewhat justified - it was not clear what empirical payoff decentralized exchange was delivering.

However, in the past two or three years, the situation has changed greatly. First, Lagos and Wright (2005) have shown that if prices are determined by Nash bargaining, the costs of inflation associated with a given "money demand curve" depend in a quantitatively significant fashion on the bargaining power of the seller. Their results are reinforced by the work of Head and Kumar (2005) and Lagos and Rocheteau (2005). Bargaining matters for monetary economics.

Second, it was traditional in the random-matching literature to assume that all trading pairs use the same bargaining protocol. Ravikumar and Wallace (2001) and Zhu and Wallace (2004) relax this assumption. The premise of these papers is that in models with pairwise trade, the correct notion of the core imposes relatively little discipline: Agents can only form blocking pairs, not blocking coalitions of arbitrary size. These papers use this notion of the core to show that in models with pairwise trade, there are a large number of core allocations. This set is sufficiently large so that a large number of core allocations are consistent with empirical phenomena (like rate-of-return dominance) that are difficult to 
understand using Walrasian model economies.

It is important not to make too much of these results. They certainly do not demonstrate that we learn nothing from analyses based on the Walrasian auctioneer. But the Walrasian auctioneer abstracts from many elements of real-world trade. I am convinced from the aforementioned papers that we are likely to continue to learn a lot about monetary economics, and economics more generally, by studying the implications of another kind of abstraction: All trade takes place in small groups.

\section{Nominal Rigidities}

From the work of Bils and Klenow (2004), as well as others, we know that firms change prices only infrequently. ${ }^{6}$ In my view, to be regarded as empirically relevant, a monetary model must be consistent with this fact. I do not mean, of course, that we should simply embed the infrequent price changes into the models as being an immutable characteristic of technology. But I do mean that the infrequent price changes should emerge as an equilibrium phenomenon.

Here, I suspect that the notion of the pairwise core developed by Wallace and his coauthors might be helpful. In a recent working paper, Hall (2004) shows how sticky wages lie in the pairwise core of an economy of workers and employers. The idea is that a matched worker and employer agree on last year's average wage, as long as that wage lies between their reservation values. Otherwise, they set the wage to the worker's reservation value or the employer's, depending on which one is closest to last year's average wage.

Hall's model is a nonmonetary one. However, my guess is that his reasoning should extend to nominal quantities in a monetary economy. This kind of logic would also explain why prices do in fact change in response to sufficiently large monetary shocks.

\section{Implementation}

The problem of implementation has received a lot of attention in the applied money literature. We may know that the government can set its monetary and fiscal variables in such a way that a desirable outcome is an equilibrium. But what if other much less desirable outcomes are also equilibria? We need to construct specifications of policy such that only desirable outcomes emerge as equilibria. As we build good basic theories of monetary policy, we will need to keep this problem in mind. Also note that this problem will be even more pernicious if we focus on core allocations of economies with pairwise trade.

\section{Dialogue}

Economic research into money and monetary policy proceeds in many different ways. That is as it should be-monetary economics is a complex subject that warrants a number of different approaches. But the lack of contact and dialogue between the various groups of scholars is mystifying to me. People who work in the basic money literature tend to be dismissive of the applied literature - and of course the reverse is true as well. We saw some communication across groups at MME2. I hope that we see a lot more in the years before MME3. It is only with such communication that we can make progress on the wide variety of important outstanding questions that confront us.

\footnotetext{
${ }^{6}$ Bils and Klenow emphasize that prices change more frequently in their sample than is typically assumed in the applied literature. Nonetheless, they find that half of goods' prices do last five months or more.
} 
Optimal Monetary Policy

Narayana R. Kocherlakota

\section{References}

Atkinson, A. B., and J. Stiglitz. 1976. The design of tax structure: Indirect vs. direct taxation. Journal of Public Economics 6 (July-August): 55-75.

Berentsen, A., G. Camera, and C. Waller. 2005. The distribution of money balances and the nonneutrality of money. International Economic Review 46 (May): 465-87.

Bhattacharya, J., J. Haslag, and A. Martin. 2005. Heterogeneity, redistribution, and the Friedman rule. International Economic Review 46 (May): 437-54.

Bils, M., and P. Klenow. 2004. Some evidence on the importance of sticky prices. Journal of Political Economy 112 (October): 947-85.

Chari, V. V., L. J. Christiano, and P. J. Kehoe. 1996. Optimality of the Friedman rule in economies with distorting taxes. Journal of Monetary Economics 37 (April): 203-23.

Correia, I., and P. Teles. 1999. The optimal inflation tax. Review of Economic Dynamics 2 (April): $325-46$.

Correia, I., J-P. Nicolini, and P. Teles. 2002. Optimal fiscal and monetary policy: Equivalence results. Manuscript. Federal Reserve Bank of Chicago.

da Costa, C., and I. Werning. 2003. On the optimality of the Friedman rule with heterogeneous agents and non-linear income taxation. Manuscript. http://epge.fgv.br/portal/arquivo/1520.pdf.

Diamond, P. A., and J. A. Mirrlees. 1971. Optimal taxation and public production I: Production efficiency. American Economic Review 61 (June): 8-27.

Friedman, M. 1969. The optimum quantity of money. In The optimum quantity of money and other essays, 1-50. Chicago: Aldine.

Golosov, M., N. Kocherlakota, and A. Tsyvinski. 2003. Optimal indirect and capital taxation. Review of Economic Studies 70 (July): 569-87.

Green, E., and R. Zhou. 2005. Money as a mechanism in a Bewley economy. International Economic Review 46 (May): 351-71.

Hall, R. E. 2004. Employment efficiency and sticky wages: Evidence from flows in the labor market. Manuscript. Stanford University.

Head, A., and A. Kumar. 2005. Price dispersion, inflation, and welfare. International Economic Review 46 (May): 533-72.

Kimbrough, K. P. 1986. The optimum quantity of money rule in the theory of public finance. Journal of Monetary Economics 18 (November): 277-84.
Kiyotaki, N., and J. H. Moore. 2005. Liquidity and asset prices. International Economic Review 46 (May): 317-49.

Kiyotaki, N., and R. Wright. 1989. On money as a medium of exchange. Journal of Political Economy 97 (August): 927-54.

1991. A contribution to the pure theory of money. Journal of Economic Theory 53 (April): 215-35.

Lagos, R., and G. Rocheteau. 2005. Inflation, output, and welfare. International Economic Review 46 (May): 495-522.

Lagos, R., and R. Wright. 2005. A unified framework for monetary theory and policy analysis. Journal of Political Economy 113 (June): 463-84.

Lucas, R. E., Jr., and N. L. Stokey. 1987. Money and interest in a cash-in-advance economy. Econometrica 55 (May): 491-513.

Phelps, E. 1973. Inflation in the theory of public finance. Swedish Journal of Economics 75 (March): 67-82.

Ravikumar, B., and N. Wallace. 2001. A benefit of uniform currency? Manuscript. Pennsylvania State University.

Rocheteau, G., and R. Wright. 2005. Money in search equilibrium, in competitive equilibrium, and in competitive search equilibrium. Econometrica 73 (January): 175-202.

Schmitt-Grohé, S., and M. Uribe. 2004. Optimal fiscal and monetary policy under sticky prices. Journal of Economic Theory 114 (February): 183-209.

Shi, S. 1995. Money and prices: A model of search and bargaining. Journal of Economic Theory 67 (December): 467-96.

1997. A divisible search model of fiat money. Econometrica 65 (January): 75-102.

2005. Nominal bonds and interest rates: The case of one-period bonds. International Economic Review 46 (May): 579-612.

Sidrauski, M. 1967. Rational choice and patterns of growth in a monetary economy. American Economic Review 57 (May): 534-44.

Trejos, A., and R. Wright. 1995. Search, bargaining, money and prices. Journal of Political Economy 103 (February): 118-41.

Zhu, T., and N. Wallace. 2004. Co-existence of money and higher-return assets as a bargaining norm. Manuscript. Pennsylvania State University. 